\title{
CCXXXVI. ELECTROPHORESIS OF PEPSIN
}

\author{
By A. TISELIUS, G. E. HENSCHEN, AND H. SVENSSON \\ From the Institute of Physical Chemistry, University of Upsala
}

(Received 8 June 1938)

The first investigation of the behaviour of pepsin in an electric field was published by Michaelis \& Davidsohn [1910]. They attempted to determine the sign of the charge on commercial pepsin ("purissimum Grübler") in the $p \mathrm{H}$ range $1 \cdot 0-4 \cdot 3$, using the well-known Michaelis transference apparatus. After passing current through the apparatus, qualitative tests were made for pepsin in the compartments above the stopcocks. They found that pepsin is negatively charged at $p \mathrm{H}>3 \cdot 7$, positively charged at $p \mathrm{H}<2 \cdot 0$, and within this interval shows migration towards both sides. This latter phenomenon was also observed at very acid reaction $(0 \cdot 1 \mathrm{H} \mathrm{HCl})$. The isoelectric point, obtained by taking the average of the hydrogen ion concentrations corresponding to the $p H$ limits mentioned, is given as $c \mathrm{H}^{+} 5 \cdot 5 \times 10^{-3}$, or $p \mathrm{H}=2 \cdot 25$.

Since, according to later investigations of the electrophoresis of proteins, mobility is a linear function of $p \mathrm{H}$ and not of $c \mathrm{H}^{+}$in the neighbourhood of the isoelectric point, it would seem preferable to take the average of the $p \mathrm{H}$ values, which would give $p \mathrm{H} 2 \cdot 85$ for the isoelectric point.

Ringer [1915], using a similar apparatus but a purified pepsin preparation, obtained somewhat different results: the enzyme showed anodic migration even in the most acid solutions and consequently had no isoelectric point. Addition of protein decomposition products (pepton Grübler), however, caused a partial cathodic migration in acid solution, which was interpreted as due to partial combination with the enzyme. On the other hand the electrochemical properties of crystalline pepsin, first prepared by Northrop, again indicate an isoelectric point of 2.8 (solubility minimum, titration curve, electrophoresis of particles of finely ground crystals) according to observations by Northrop himself [1930]. Ågren \& Hammarsten [1937] in a recent paper made some interesting measurements on the electrophoresis of solutions of a crystalline pepsin preparation in the apparatus of $\mathrm{H}$. Theorell. At $p \mathrm{H} 2 \cdot 27$ and $2 \cdot 30$ they found positive migration, at 3.34 negative, which would also indicate an isoelectric point around 2.8. A certain separation of peptic activity and total nitrogen was observed at $p H$ 3.34, but at more acid reaction both migrated together. However, in recent measurements with a different material Ågren found only negative migration for pepsin (private communication).

The question of the electrophoretic homogeneity of pepsin was dealt with in considerable detail already by Ringer in his work referred to above, which is interesting because it also seems to be the first attempt to use electrophoretic methods for the study of enzymic homogeneity and for purification of enzymes (ptyalin and pepsin). Ringer worked with pepsin prepared, according to Pekelharing, from dog's gastric juice, by dialysis and by precipitation with ammonium sulphate. To explain why the pepsin showed no isoelectric point, but yet had a marked $p \mathrm{H}$-solubility minimum, Ringer assumed that the enzyme 
was partially combined with protein, which would show positive charge at acid reactions. Electrophoresis in $0.025 \mathrm{~N} \mathrm{HCl}$ gave, in fact, an anodic portion of high activity, whereas the cathodic portion was inactive but nevertheless contained much protein. At $p \mathrm{H} \mathrm{4.1}$ no such separation was observed. As regards the dependence of the separation on $p H$ Ringer's results are therefore contrary to Hammarsten's and Ågren's.

The following is an account of some experiments on the electrophoretic behaviour of solutions of crystalline pepsin. The apparatus and procedure earlier described by one of us [Tiselius, 1937, 1] were used. This method has several advantages, e.g. diminished risk of heat convection, possibility of simultaneous analytical and optical observation of the migration, and of more effective separation by applying higher voltage and the "compensation" device for balancing the migration.

A number of different crystalline pepsin preparations were investigated, which will be designated below by I, II, III $a$ and III $b$. Pepsin I had been prepared according to Philpot's modification of Northrop's procedure [Philpot, 1935; Philpot \& Small, 1938] and formed beautiful crystals about $0.5 \mathrm{~mm}$. in length. Pepsin II was a glycerol solution of crystals (twice crystallized Cudahy Pepsin 12-7-3) prepared in Dr Northrop's laboratory, according to the procedure developed there. Philpot \& Small (unpublished) have found that pepsin can be fractionated by salt precipitation to give an easily soluble crystalline fraction, and a less soluble non-crystalline fraction with a solubility minimum at $p \mathbf{H} 3 \cdot 8$, the latter having a somewhat lower specific activity (private communication of the authors). Samples of these two preparations dissolved in acetate buffer were kindly provided by Dr Philpot, and will be designated below as III $a$ and III $b$ respectively. The authors wish to express their thanks to Drs Northrop, Philpot and Small for generously placing material and information at their disposal.

The crystals were dissolved in the buffer solution to be used; the other preparations were first dialysed to remove glycerol. Before filling the apparatus all samples were dialysed overnight against the buffer to be used as a supernatant. Nitrogen was determined by the micro-Kjeldahl method, peptic activity by the haemoglobin method [Anson \& Mirsky, 1932]. Like Philpot \& Small [1938] we have found that the absolute values of specific activities by this method are somewhat dependent upon the preparation of haemoglobin used. Throughout this work, therefore, a single haemoglobin preparation was used.

Preliminary electrophoresis measurements showed that the various preparations contained one definite protein component of fairly homogeneous migration, with only small differences in migration velocity. Besides the sharp boundary given by this component, a very diffuse boundary could be observed, at least in concentrated solutions (more than $0.5 \%$ ), indicating the presence of inhomogeneous material.

The final experiments involved optical determinations of the mobility of the main component at different $p H$ (Table I, Fig. 1); in a number of experiments the optical observation was supplemented by analysis of the different compartments for nitrogen and peptic activity (Table II, Fig. 1), in order not only to correlate the activity migration with the migration of the main component but also to see how far the specific activity could be raised by electrophoretic separation. As the "analytical" experiments for this latter purpose were usually run for a much longer time, a higher buffer concentration (ionic strength $0 \cdot 1$ ) was used than in the "optical" series (ionic strength 0.02 ). In prolonged electrophoresis experiments disturbances due to electrolyte transport occur much more easily in dilute salt media than in more concentrated solutions. 


\section{A. TISELIUS, G. E. HENSCHEN AND H. SVENSSON}

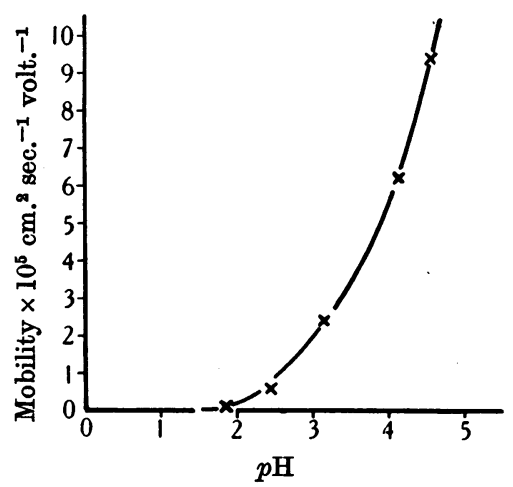

Fig. $1 a$.

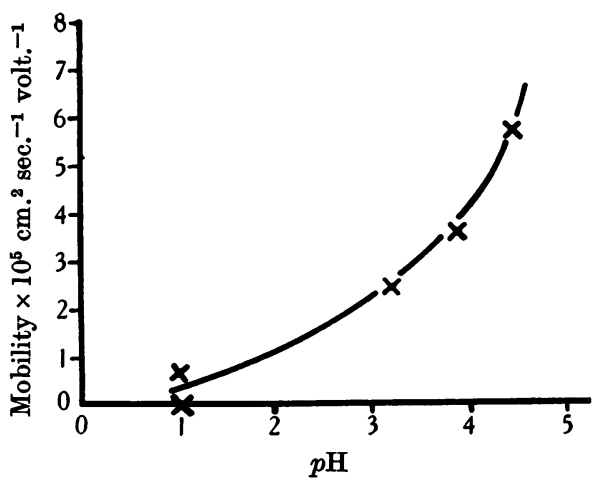

Fig. $1 b$.

Fig. 1. Electrophoretic mobilities of the active component in pepsin at $0^{\circ}$ and ionic strengths $(a) 0.02$ and $(b) 0 \cdot 1$.

Table I. Electrophoretic migration velocity of main component in solutions of crystalline pepsin

Optical observation. Buffer ionic strength 0.02. Pepsin conc. 0.2-0.3\%. Temp. $0^{\circ}$.

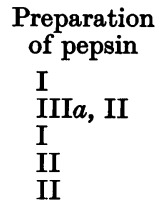

$\begin{array}{lcc}\text { Buffer } & p \mathrm{H} & \begin{array}{c}\text { Mobility } \times 10^{5} \\ \mathrm{~cm}^{2} \text { volt }^{-1} \text { sec. }^{-1}\end{array} \\ \text { Acetate } & 4 \cdot 57 & -9 \cdot 4 \\ \text { Acetate } & 4 \cdot 15 & -6 \cdot 2 \\ \text { Citrate, HCl } & 3 \cdot 16 & -2 \cdot 4 \\ \text { Citrate, HCl } & 2 \cdot 47 & -0 \cdot 6 \\ \text { Citrate, HCl } & 1 \cdot 87 & -0 \cdot 1\end{array}$

Determinations in $0 \cdot 1 \mathrm{~N} \mathrm{HCl}, p \mathrm{H} 1.08$ gave values for the mobility varying between 0.0 and $-0.4 \times 10^{-5}$. The variation is probably due to the fact that the experimental error in this medium is much greater (too low buffering action). No positive migration could be observed in any of the preparations.

\section{Table II. Electrophoretic migration and fractionation of solutions of crystalline pepsin}

Optical and analytical methods used simultaneously. Ionic strength of buffer $=0 \cdot 1$. Temp. $0^{\circ}$.

\begin{tabular}{|c|c|c|c|c|c|c|c|c|c|}
\hline \multirow[b]{2}{*}{$\begin{array}{l}\text { Prepara- } \\
\text { tion of } \\
\text { pepsin }\end{array}$} & \multirow[b]{2}{*}{ Buffer } & \multirow[b]{2}{*}{$p \mathrm{H}$} & \multirow[b]{2}{*}{$\begin{array}{l}\text { Potential } \\
\text { gradient } \\
\text { volt } / \mathrm{cm} .\end{array}$} & \multirow[b]{2}{*}{$\begin{array}{l}\text { Time } \\
\text { min. }\end{array}$} & \multicolumn{3}{|c|}{ Mobility $\times 10^{5} \mathrm{~cm}^{2}$ volt $^{-1}$ sec. $^{-1}$} & \multicolumn{2}{|c|}{$\begin{array}{c}\text { Specific activity } \\
{[\text { P.U. }]_{\mathrm{mg} .}^{\mathrm{Hb}} \text { total } \mathrm{N}}\end{array}$} \\
\hline & & & & & $\begin{array}{c}\text { Peptic } \\
\text { activity }\end{array}$ & $\begin{array}{c}\text { Total } \\
\text { nitrogen }\end{array}$ & $\begin{array}{l}\text { Main com- } \\
\text { partment } \\
\text { (optical ob- } \\
\text { servation) }\end{array}$ & $\begin{array}{l}\text { Original } \\
\text { solution }\end{array}$ & $\begin{array}{l}\text { Top + com- } \\
\text { partment at } \\
\text { end of exp. }\end{array}$ \\
\hline I & Citrate $\mathrm{HCl}$ & $3 \cdot 19$ & $7 \cdot 64$ & 195 & $-2 \cdot 68$ & $-1 \cdot 38$ & $-2 \cdot 42$ & $0 \cdot 162$ & 0.273 \\
\hline I & $\mathrm{HCl}$ & 1.08 & 3.06 & 315 & +0.0 & +0.6 & +0.0 & $0 \cdot 177$ & 0.246 \\
\hline II & Acetate & $4 \cdot 41$ & $7 \cdot 65$ & 595 & - & - & $-5 \cdot 65$ & 0.214 & $0 \cdot 344$ \\
\hline II & Citrate $\mathrm{HCl}$ & $3 \cdot 19$ & $9 \cdot 30$ & 515 & _ & - & $-2 \cdot 40$ & 0.213 & $0 \cdot 324$ \\
\hline III $a$ & Citrate $\mathrm{HCl}$ & $3 \cdot 19$ & $9 \cdot 04$ & 597 & - & - & -2.50 & $0 \cdot 240$ & $0 \cdot 314$ \\
\hline III $b$ & Citrate $\mathrm{HCl}$ & $3 \cdot 19$ & $9 \cdot 39$ & 493 & - & - & $-2 \cdot 32$ & 0.175 & 0.250 \\
\hline
\end{tabular}

The first two experiments in Table II were made with the purpose of measuring migration velocities by the three different methods simultaneously, whereas in the others we tried to obtain an appreciable separation by prolonged migration (the main protein component migrated from 64 to $154 \mathrm{~mm}$.) in combination with compensation [Tiselius, 1937, 2]. Under these circumstances a change in the 
composition of the bottom compartment was unavoidable and calculations of mobilities from analytical measurements in the usual way became impossible.

The results obtained in the experiments described in Tables I-II and Fig. l $a, b$ may be summarized as follows. Solutions of crystalline pepsin, prepared by various methods, were in no case found to be quite homogeneous in electrophoresis, but contained some inactive nitrogen which could be removed by electrophoretic separation. In this way the specific activities of the various samples could be raised by $31-69 \%$. From the agreement between the mobilities (Table II, 6th and 8th columns) it is concluded that the peptic activity is associated with a protein component, which shows fairly homogeneous migration (does not give rise to more than one "schlieren" band in the optical observation arrangement). This protein in the $p \mathrm{H}$ range investigated ( $p \mathrm{H} 1.08-4.57)$ carries a negative charge and shows no isoelectric point and thus behaves electrophoretically like an acid. Even a pepsin preparation which showed a solubility minimum at $p H 3.8$ (last experiment in Table II) behaved in principle in the same way.

Our experiments thus to a certain extent give further support to the view expressed by Northrop that the enzyme pepsin is a protein, but it is quite clear that pepsin crystals contain considerable amounts of inactive material, which may be removed by electrophoresis, and it seems likely that this material influences some of the properties of pepsin, such as solubility and acid-base combining capacity, in a marked way. The specific activity of crystalline pepsin according to Anson \& Mirsky is 0.184 [P.U.] ${ }_{\mathrm{mg} \text {. protein } \mathrm{N}}^{\mathrm{Hb}}$, but in a recent publication by Herriot [1938] a higher value is given $(0 \cdot 26)$. We have preferred to refer our values to total nitrogen instead of protein nitrogen and (as seen from Table II) we obtained activities ranging from 0.162 to 0.240 for our starting material, but as high a value as 0.344 [P.U.] $]_{\mathrm{mg} \text {. total } \mathrm{H}}^{\mathrm{Hb}}$ for our most active fraction. In comparing these values with those obtained by other authors one must make the reservation that the haemoglobin preparations were not quite identical [see also Philpot \& Small, 1938].

As regards the question of the homogeneity of pepsin it should be observed that the electrophoretic procedure is a very gentle separation method and could not break down a loose association complex, unless this were appreciably dissociated into its components. The homogeneity of the migration of the active component as found in the experiments described above is not therefore sufficient evidence per se for the chemical individuality of this enzyme, especially as the most active fractions obtained from different materials did not show the same specific activity (Table II). More experiments over a wider $p H$ range and with systematically varied preparation methods are needed to clarify this question.

The somewhat surprising result that pepsin is not positively charged even in the most acid solutions investigated $(p H \mathrm{H}$ 1.08) may possibly be due to an unusual tendency of the pepsin to combine with anions of the electrolyte medium. Such an effect has been previously found [Tiselius, 1930] for egg albumin, although not to as marked an extent as one would have to assume for pepsin to account for the above results. This would explain why, in the most acid solutions, the negative charge is larger when the ionic strength increases from 0.02 to $0 \cdot 1$ (see Fig. 1), contrary to the usually observed decrease in electrophoretic mobility with increasing salt concentration. 


\section{SUMmaRY}

Electrophoretic measurements show that the enzymic activity of solutions of crystalline pepsin, prepared by different methods, migrates as a homogeneous protein component with a negative charge and with no isoelectric point. Some inactive, inhomogeneous protein or protein breakdown material is left behind, and the specific activity may thus be raised by $31-69 \%$.

The authors are indebted to Prof. Svedberg for his kind interest in this investigation, and to the Nobel, Rockefeller, and Wallenberg Foundations for financial support.

\section{REFERENCES}

Ågren \& Hammarsten (1937). Enzymologia, 4, 49.

Anson \& Mirsky (1932). J. gen. Physiol. 16, 59.

Herriot (1938). J. gen. Physiol. 21, 501.

Michaelis \& Davidsohn (1910). Biochem. Z. 28, 1.

Northrop (1930). J. gen. Physiol. 13, 739.

Philpot (1935). Biochem. J. 29, 2458.

— \& Eriksson-Quensel (1933). Nature, Lond., 132, 932.

_ \& Small (1938). Biochem. J. 32, 542.

Ringer (1915). Hoppe-Seyl. Z. 95, 195.

Tiselius (1930). Nova Acta Reg. Soc. Scient. Upsal. 7, 4 (Dissertation.)

- (1937, 1). Trans. Faraday Soc. 33, 524.

- (1937, 2). Biochem. J. 31, 1464.

- (1938). Svensk Kem. Tidskr. 50, 58 (in English). 